СМУ-3.

\title{
ИЗОТОПНЫЙ СОСТАВ УГЛЕРОДА ПЧЕЛ И ПРОДУКТОВ ИХ ЖИЗНЕДЕЯТЕЛЬНОСТИ
}

Калашникова Д.А., Симонова Г.В., Гераскевич А.В.

ФГБУН Институт мониторинга климатических и экологических систем СО РАН,

Томск, Россия

terrezaprk@mail.ru

DOI: 10.26902/ASFE-11_83

Метод изотопной масс-спектрометрии широко используется для анализа подлинности меда в отношении его географического происхождения [1] и его фальсификации [2]. Для других продуктов пчеловодства, не так важных с коммерческой точки зрения, нет международных стандартов анализа и исследования в этой области ограниченны.

В работе представлен предварительный анализ результатов измерений изотопного состава углерода $\left(\delta^{13} \mathrm{C}\right)$ пчел и продуктов их жизнедеятельности (мед, пыльцевая обножка, воск, прополис), отобранных на пасеках Томской области, а также для сравнения в Алтайском, Краснодарском краях и Кемеровской области (рис. 1). Изотопный анализ проведен с использованием изотопного масс-спектрометра DELTA V Advantage (Thermo Fisher), совмещенного с элементным анализатором Flash 2000 (ТомЦКП СО РАН). Показано, что независимо от географического места происхождения вариации величины $\delta^{13} \mathrm{C}$ подмора пчел, прополиса и воска незначительны и составляют величину $-26,1 \pm 0,4 \%,-27,4 \pm 0,5 \%$ и $28,4 \pm 0,6 \%$, соответственно. Вариации $\delta^{13} \mathrm{C}$ в медах составили величину $-26,6 \pm 1,1 \%$, а в пыльцевой обножке $-27,7 \pm 1,6 \%$, что обусловлено географическим местоположением и разнообразием кормовой базы пчел.

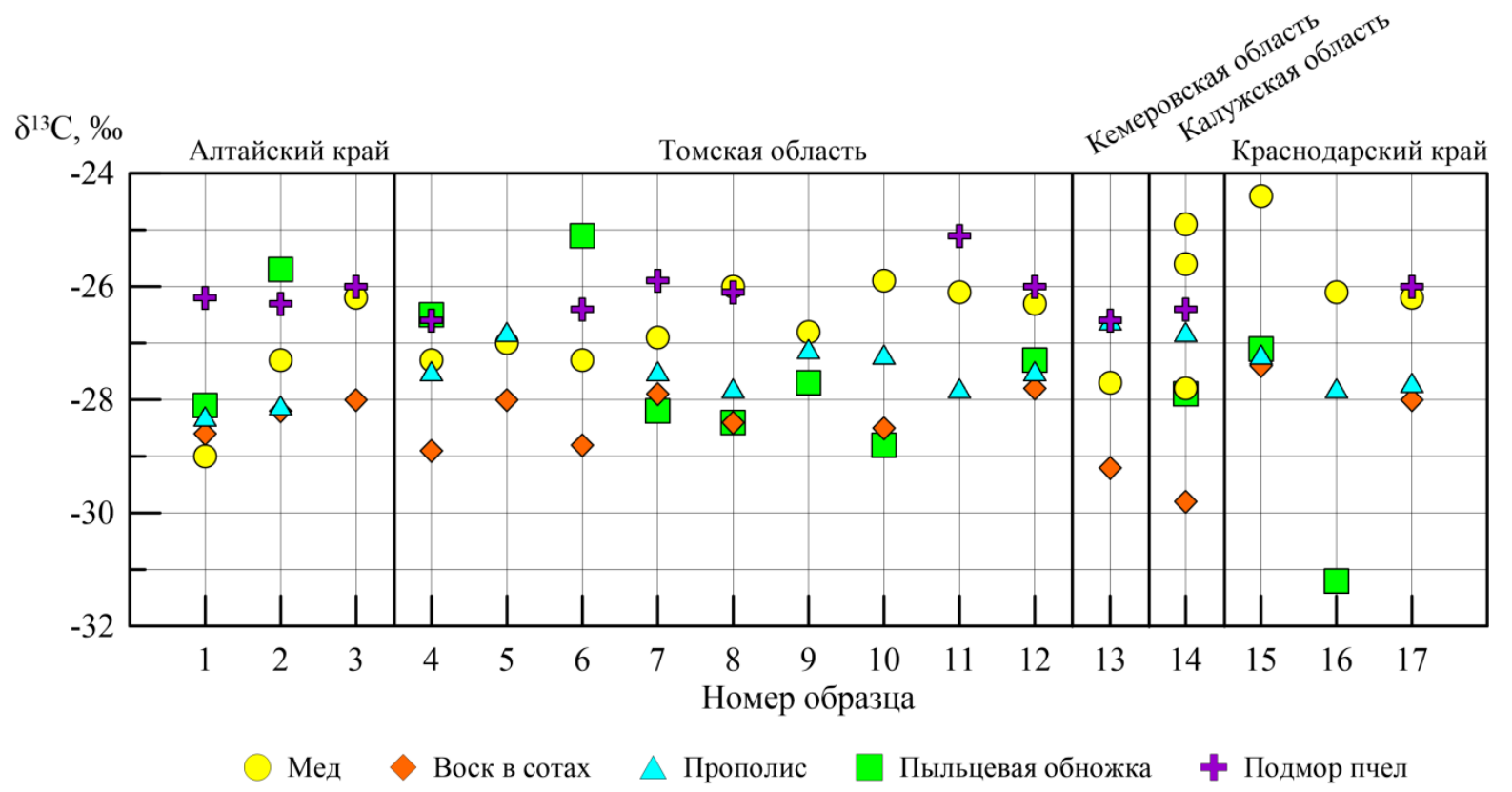

Рис.1. Величина $\delta^{13}$ С пчел и продуктов их жизнедеятельности

\section{Список литературы}

1. Carter J.F., Chesson L.A. Food Forensics: Stable Isotopes as a Guide to Authenticity and Origin. Boca Raton FL: CRC Press, 2017. 352 p.

2. Ветрова О.В., Калашникова Д.А., Мелков В.Н., Симонова Г.В. Выявление фальсификации меда сахарными сиропами методом масс-спектрометрии стабильных изотопов // Журн. аналит. химии. 2017. № 7. Том 72. С. 645.

Работа выполнена при финансовой поддержке РФФИ в рамках научного проекта № 19-34-90016. 